Article

\title{
Embedded Deforestation: The Case Study of the Brazilian-Italian Bovine Leather Trade
}

\author{
Aynur Mammadova* $*$, Mauro Masiero $\mathbb{D}$ and Davide Pettenella $\mathbb{D}$ \\ TESAF Department, University of Padova, Viale dell'Università, 16, 35020 Legnaro PD, Italy; \\ mauro.masiero@unipd.it (M.M.); davide.pettenella@unipd.it (D.P.) \\ * Correspondence: aynur.mammadova@phd.unipd.it
}

Received: 11 February 2020; Accepted: 20 April 2020; Published: 22 April 2020

\begin{abstract}
Deforestation and forest degradation driven by Agriculture, Forestry and Other Land Use (AFOLU) are important sources of carbon emissions. Market globalization and trade liberalization policies reinforce this trend and risk deforestation to be embedded in global value chains. Due to the complexity of global production and trade systems, deforestation risk is also embedded in the supply chains of the products and sectors that are not direct deforestation drivers. Bovine leather is a commodity closely entangled in the debates about deforestation as it is a by-product of cattle. This research focuses on leather trade between Brazil and Italy to demonstrate the channels through which Italian imports of Brazilian leather could possess embedded Amazonian deforestation and related risks. The data employed for the analysis was searched at three different levels for the leather trade between Brazil and Italy: (a) the country level annual leather trade statistics for the years 2014-2018 taken from the Comtrade database; (b) the state level leather trade data, for the years 2014-2018 taken from the Comexstat database; and (c) the exporter-importer level leather trade data for the period of August 2017-August 2018, based on customs declarations. The analysis helps to demonstrate that the Italian leather trade with Brazil possesses the risk of deforestation unless the proper traceability and due diligence systems are in place to claim the opposite. The European and Italian leather industry need to be more proactive in acknowledging the existence of the risk at different levels, putting full traceability systems in place and sending out clear market signals that deforestation is not tolerated, and that sustainability is valued.
\end{abstract}

Keywords: Brazilian Legal Amazon; leather; trade; forest-risk commodities; consumption; deforestation

\section{Introduction}

Deforestation and forest degradation are important sources of carbon emissions aggravating the current climate crisis. The studies show that on average around 15\% of global greenhouse gas (GHG) emissions result directly from deforestation and about $8 \%$ from tropical deforestation [1,2]. The majority of these emissions come from the transformation of vast territories to croplands and pastures as a follow-up activity to forest clearing. The International Panel on Climate Change's (IPCC) special report published in 2019 indicates that as direct drivers of deforestation and forest degradation, Agriculture, Forestry and Other Land Use (AFOLU) were responsible for $23 \%$ of the total net anthropogenic GHG emissions for the period 2007-2016 [3]. Market globalization, trade liberalization policies and global value chain development reinforce this trend and risk to ease the access of products with an unsustainable origin in international markets. As a result, deforestation becomes embedded as a negative externality in "a produced, traded or consumed product, good, commodity or service" [4] (p. 14).

Since Brazil became a global powerhouse of agricultural production and export, its natural ecosystems have experienced serious damage as well [5-7]. The agricultural development in the 
country in the period 1985-2018 transformed around 65 million hectares (Mha) of native ecosystems to pasture or croplands in the Brazilian Legal Amazon (BLA) [8]. Despite the 70\% reduction of annual deforestation in 2004-2015, it has increased to reach around $9800 \mathrm{~km}^{2} /$ year and being associated with devastating forest fires in 2019 [9,10]. The forest fires of 2019 were mostly attributed to the "slash and burn" practices of cattle farmers in agriculture frontier states, such as Pará, Mato Grosso, Amazonas, etc. [11]. According to the estimates of the Organization for Economic Cooperation and Development (OECD), by 2030 Brazil will strengthen its leading position in producing soybeans, and its exports will outperform global trade growth for maize and beef [12]. There is a global concern that accelerated production and trade will have negative consequences by pushing the forests to the tipping point in the Amazon and Cerrado biomes [13].

Cropland and cattle pasture driven deforestation in Brazil has been addressed in research since the 1990s-with diverse foci, including the drivers, actors and case studies [5,14-17]. Although early research has focused on the typology of the actors at the local level, more recent studies shift the focus on the role of global markets as the main drivers of deforestation [7,14,18]. In addition to peer-reviewed research articles, geospatial mapping and other types of data analysis conducted by Brazil-based institutions provide a plethora of evidence for the direct correlation between commodity production and land-use conversion. For example, the recent data by Mapbiomas [19] suggests that 40.8 Mha of net native vegetation loss equals around the same area of a net gain in pastureland from 1985 to 2017 in the Amazon biome.

One of the important products derived from cattle is bovine leather. This commodity is closely entangled in the debates about BLA deforestation thanks to being a by-product of cattle. On average, Brazil exports around $80 \%$ of its bovine leather to global markets [17]. The exposure to deforestation is embedded in the supply chain of the leather originating from Brazil and is carried to international markets. However, addressing the deforestation risk along the bovine leather supply chain is very challenging due to supply chain and trade complexities, as well as diverse political discourses that frame the risk differently [20]. A closer look at global trade interactions helps to identify the exposure of the leather supply chains to deforestation in Brazil.

The EU is Brazil's second-biggest trading partner, accounting for 18.3\% of its total trade. In 2017 the total value of Brazilian exports to Europe was equal to 30.7 billion United States Dollars (USD), $50 \%$ of which were agricultural products, followed by metals and minerals $(33 \%)$ and forest products (10\%). From a business and investment perspective, the EU-Brazilian relations can be categorized on three fronts: trade, investments and financial assistance from banks and other financial institutions. Brazil is the single largest exporter of agricultural products to the EU after China. Besides direct trade, the EU is also the biggest foreign investor in Brazil. In 2015, the EU invested 48.5\% of its Latin American investments in Brazil [21]. Due to trade relations and global supply chains, the potential embedded deforestation in commodity production also travels to European markets. According to the estimates by Pendrill et al. [22] (p. 20), Italy (with Germany) leads European Union (EU) imports of embedded deforestation, importing about 3\% of the globally estimated embedded deforestation. The embedded deforestation in the EU imports goes beyond the supply chains of major forest-risk commodities as the EU is also the second-biggest importer of by-products, such as bovine leather [23].

Among European countries, Italy ranks among the top 10 European investors in Brazil in terms of foreign direct investments (FDI) [24]. Besides, Italy channels 50\% of its total FDI to Brazil through the Netherlands, the biggest investor country in Brazil [24]. It ranks fourth among EU countries that trade with Brazil and it holds a leading position for some forest-risk commodities [25]. Globally, Italy is the second major importer of Brazilian bovine leather after China. Adult bovine leather is the main raw material used by the Italian tanning industry accounting for $71 \%$ of the total production. The most important end-use markets of Italian finished leather are footwear (42\%), leather goods (24\%), furniture (16\%), upholstery (11\%) and clothing (5\%) [26] (see Appendix A for more information about the Italian tanning industry). 
Taking into consideration the important roles of Brazil and Italy as, respectively, exporter and importer, this paper focuses on bovine leather trade between these two countries. It aims to demonstrate the channels through which Italian imports of Brazilian leather could possess embedded deforestation and related business risks. By combining the assessment of the embedded deforestation in two new arenas-within the non-conventional commodity chain and in trade-we want to discuss an example we think relevant to illustrate the width and depth of the concept of embedded deforestation.

The paper proceeds as follows: After a review of the literature on embedded deforestation connected to global trade and finance (Section 1.1), we introduce the data collection and methods (Section 2). The description of the main results follows in the third section, which is organized in two parts: in the first one we provide the data on Italian import of leather from Brazil, and in the second one we discuss embedded deforestation as a reputational and legal risk for the Italian leather trade. The two last sections present the discussion and the conclusion with suggestions for further research.

\subsection{Embedded Deforestation in Current Global Trade and Finance}

The latest progress report of 2014 New York Declaration on Forest (NYDF) shows that the political ambition of "halving tropical deforestation by 2020 and ending it by 2030" is far from being on track and, on the contrary, since the NYDF was endorsed, the average annual humid tropical primary forest loss has accelerated by $44 \%$ [27]. Among the important drivers for these trends, the report is pointing out the global trade and market demand for agricultural commodities, the production of which leads to deforestation and land-use change in the tropics. The letter addressed to the European Commission by 24 national and international non-governmental organizations (NGOs) in 2019 [28] points out that "removing trade barriers with this [Mercosur] region would increase European demand for cheap, unsustainable agricultural products and biofuels from South America, drive additional deforestation and conflicts over land, contribute to wildlife trafficking, biodiversity loss, and higher overall greenhouse gas (GHG) emissions". In a letter published in Science in 2019, more than 600 scientists and 300 Brazilian indigenous groups urged the EU to reconsider the trade agreement and put human rights and deforestation above economic gains [29]. The indigenous communities in Brazil and organizations such as Amazon Watch and Global Witness trace the destruction of forests to European and North American financial flows and investments by large investors, including international banks. They call for EU-led sanctions and boycotts on the Brazilian commodity trade and due diligence for financial investments as a strategy to avoid embedded deforestation [30,31].

The role of global commodity trade as an indirect driver of deforestation has been studied for years. By focusing on BLA and using standard and spatial econometrics, Faria and Almeida [32] argue that the increase in openness to trade and increase in deforestation are positively correlated. Harstad and Mideksa [33] argue that trade liberalization makes it beneficial to capture market share by discouraging competitors and, as a result, illegal deforestation gains positive signals. Agriculture-driven deforestation is affected by agricultural output prices: if trade liberalization increases local agricultural prices, then liberalization reinforces and deforestation increases [34].

The literature also analyses environmental and social impacts of trade and finance in terms of GHG emissions, reduction of forest cover, loss in biodiversity and indigenous community welfare conditions. By looking at a land-use change in a globalized world, Friis and Nielsen [35] discussed the socio-economic and environmental interactions, feedback mechanisms and spillover effects over distance and across scales through the concept of "telecoupling". Pendrill et al. [36] estimate that around $29 \%-39 \%$ of deforestation-related emissions, as part of the carbon footprint of forest-risk commodities, such as beef and oilseeds, are driven by international trade. Sandström et al. [37] demonstrated that land-use change embedded in commodity production in tropical countries is an important contributor to the GHG footprints of EU diets. Kanemoto et al. [25]. point out how the international trade in commodities undermines national emissions reduction targets due to leakage of the impacts to other countries. In yet another study, Pendrill et al. [22] discuss "displaced" deforestation, as the countries that were either slowing deforestation rates or even increasing forest cover on their territories in 2005-2013 
(e.g., European countries, China, India, Russia) are also the ones that import most of the products with embedded deforestation from somewhere else. According to their estimates, embedded deforestation equaled about one-third of the net forest gains in these countries. The Transparency for Sustainable Economies (TRASE) initiative, following the methodology suggested by Godar et al. [38]—Spatially Explicit Information on Production to Consumption Systems (SEI-PCS)—connects the sub-national location of production (municipality level) to consumption (domestic and international) patterns. By connecting the data on the municipality of production, exporter, importer, trade volume and value, Godar et al. [38,39] argue that the exposure of European imports to deforestation risk of certain commodities changes compared to national-level estimations.

As the discussion on embedded deforestation in agricultural commodity imports gains more intensity, most of the assessments of the deforestation footprint and discussions in policy documents focus on the big six forest-risk commodities: timber, palm oil, beef, soy, cocoa and coffee $[36,40,41]$. Due to the complexity of global production and trade systems, deforestation appears as an embedded risk also in the supply chains of the products and the economic sectors that are not direct drivers. The quantification of embedded deforestation in these commodity chains is methodologically challenging and require thorough case-by-case risk analysis. Differentiation between commodities with direct causal links and those with exposure to deforestation in their supply chain has an impact on how responsibility and accountability are constructed. The exposure to deforestation risk can happen through three main channels. First, certain commodity productions can pose significant indirect pressure for deforestation and forest degradation through land-use change dynamics, i.e., soy in Brazil. The second channel of exposure to deforestation risk happens when forest-risk commodities are used to produce a product or commodity of another category (i.e., soy used as feed for poultry). Another identified channel of deforestation risk exposure is through the supply chains of the by-products of the main forest-risk commodities, like in the case of leather [42].

\section{Materials and Methods}

Considering the above mentioned, as well as the historical trade relations between Brazil and Italy, it is worth exploring the presence of a risk of deforestation and land-use change embedded in Brazilian-Italian trade. As a traditional bovine leather manufacturing country, Italy is importing a large share of bovine skins from Brazil. Given the role of cattle in deforestation and forest degradation in Brazil, we presume most of that impact is also embedded in the leather supply chains reaching Italy. By focusing on BLA as an administrative unit with most of the agriculture-driven deforestation, we attempt to understand the extent of the animal hides and leather originating from this area and subsequently exported to Italy. An assessment and mapping of the deforestation risk in the trade relations between the two countries could create the necessary basis for future studies on quantifying that risk or other relevant dimensions (e.g., GHG footprint) linked to deforestation.

For the assessment of the deforestation risk in the leather supply chain, we focused on the administrative unit of BLA as a scope. The administrative unit of Brazilian Legal Amazon was established by Federal Law No. 5.173 (Art. 2) and surrounds the states of Acre, Amapá, Amazonas, Pará, Rondônia, Roraima, Tocantins, Mato Grosso and part of Maranhão. Covering more than 5 million $\mathrm{km}^{2}$ (two-thirds of Brazil), Legal Amazon encompasses all the Amazon Biome, $37 \%$ of the Cerrado and $40 \%$ of the Pantanal Biome. Data on deforestation provided by the National Institute for Space Research (INPE) that monitors the deforestation since 1988 through its PRODES (Legal Amazon Deforestation Monitoring Project) is confined to the BLA borders. These are the deforestation estimates that are considered in the discussions about deforestation risk in this research [10].

With the aim to explore the extent of the deforestation risk associated with the leather trade between Brazil and Italy, we employed different data sources. For setting the scene and introducing trade and financial relations between the two countries we used the United Nations (UN) Comtrade database, Resource Trade by Chatham House and the financial reports by the Central Bank of Brazil. 
Data employed for the analysis was searched at three different levels. Each of these levels has different sources:

a. For the country-level leather trade between Brazil and Italy: annual leather trade statistics between Brazil and Italy, at the national level, for the years 2014-2018, in net weight (kg). This data is based on the public UN Comtrade database that is a repository for official international trade statistics;

b. for the state-level leather trade between Brazil and Italy: the state level leather exports from Brazil in general and the exports by Brazilian states to Italy, for the years 2014-2018, in net weight (kg). This data is based on the Comexstat database (previously, Aliceweb), the official and public Brazilian foreign trade statistics portal that allows obtaining subnational (state and municipal) level export data. The Comexstat database [41] allows filtering out exporting states and exported product categories. With regard to the origin states, we were interested in understanding the share of BLA leather exports within the total exports from the country. The municipal-level export data from Comexstat was used additionally to confirm the exports by individual exporting companies;

c. for the exporter-importer-level leather trade between Brazil and Italy: leather trade statistics between Brazil and Italy, at the individual shipment level, for the period August 2017-August 2018, in metric tons. This is based on customs declarations. Among many, the customs declarations contain the information on the date of export, exporter, product (volume or value), a port of export, country of destination and the importer (consignee - an entity who is financially responsible for the receipt of a shipment). We were able to obtain the data covering only one fiscal year.

To harmonize the data obtained from the different sources as well as for the simplicity of the analysis and communication, the results are presented based on three major steps in leather processing: (a) preservation of raw hides (salted); (b) wet-blue (or chrome-free) tanning and crust; and (c) leather finishing. These three oversimplified steps are also reflected in and consistent with the three major 4-digit Harmonized System (HS) of tariff nomenclature that is used to report trade statistics (see Table A1 (Appendix B) for a detailed description of the HS codes applicable for leather). This study focuses mainly on the leather trade based on the following HS4 codes:

- HS 4101-raw hides and skins of bovine (including buffalo) or equine animals (fresh, salted, dried, limed, pickled, otherwise preserved but not tanned, parchment dressed or further prepared), whether or not dehaired or split-hereinafter raw or salted hides;

- HS 4104-tanned or crust hides and skins of bovine (including buffalo) or equine animals, without hair on, whether or not split, but not further prepared-hereinafter wet-blue or semi-processed leather;

- HS 4107-leather further prepared after tanning or crusting, including parchment-dressed leather, of bovine (including buffalo) or equine animals, without hair on, whether or not split, other than leather of heading 41.14-hereinafter finished leather.

While imports of raw materials to Italy are relatively easy to track, the exports of highly processed leather products from Italy are more challenging to follow. This challenge is mainly due to the re-exports, but also to the granularity of the use of leather as parts of different products. In this case, products made entirely or partly from leather fall under different commodity category codes, which complicates the data mining. For example, while two-digit HS 42 (articles of leather; saddlery and harness; travel goods, handbags, and similar containers; articles of animal gut other than silkworm gut) could be allocated totally as a leather-made product category of leather articles, HS 64 (footwear; gaiters and the like; parts of such articles) requires further zoom into 4-digit codes, such as HS 6403 (footwear, with outer soles of rubber, plastics, leather or composition leather and uppers of leather) and HS 6404 (footwear, with outer soles of rubber, plastics, leather or composition leather and uppers 
of textile materials) to filter out and identify the products using leather as a raw material. Tracking finished leather to be used or already used in furniture and upholstery products, unfortunately, is much more complex. Considering these limitations, in the results section, we present data on the Italian exports of selected leather products.

Besides trade statistics, the study also refers to Google maps for searching locations of headquarters of some individual tanneries, as well as to the public information provided on the website of the Italian Tanners Association (UNIC) for understanding the market structure and specialization of the Italian leather tanning industry. The study also employs the information collected in the form of face-to-face interviews and observations during the fieldwork in Brazil in May-August 2018, and in Italy during the years of 2016-2019. This information is mainly used to fill the data gaps and interpret the results of the quantitative analysis.

\section{Results}

This section is organized into two parts. First, we present the results of the deforestation risk assessment of Brazilian exports and Italian imports of leather based on the HS codes at the country (i.e., federal), state and importer/exporter levels. To highlight the deforestation risk of Italian producers, the exports of leather products from Italy are also discussed. Second, we present embedded deforestation as a reputational and legal risk for the Italian leather trade.

\subsection{Assessing Deforestation Risk through Trade Data Analysis}

\subsubsection{Country-Level Leather Trade between Brazil and Italy}

According to the Comtrade database, Italy has been the second-biggest importer of Brazilian bovine hides and leather after China (HS 4101; 4104; 4107 combined) for many consecutive years within the period considered in this study (2014-2018). This position of the Italian import market remains the same both in terms of estimations in net weight (kg) and value (USD). Besides, the Italian imports from Brazil have also increased over the years, while Chinese (incl. Hong Kong) imports show the opposite trend [25]. In 2018, Italy imported 123 million $\mathrm{kg}$ (in net weight) bovine hides and leather from Brazil (Figure 1).

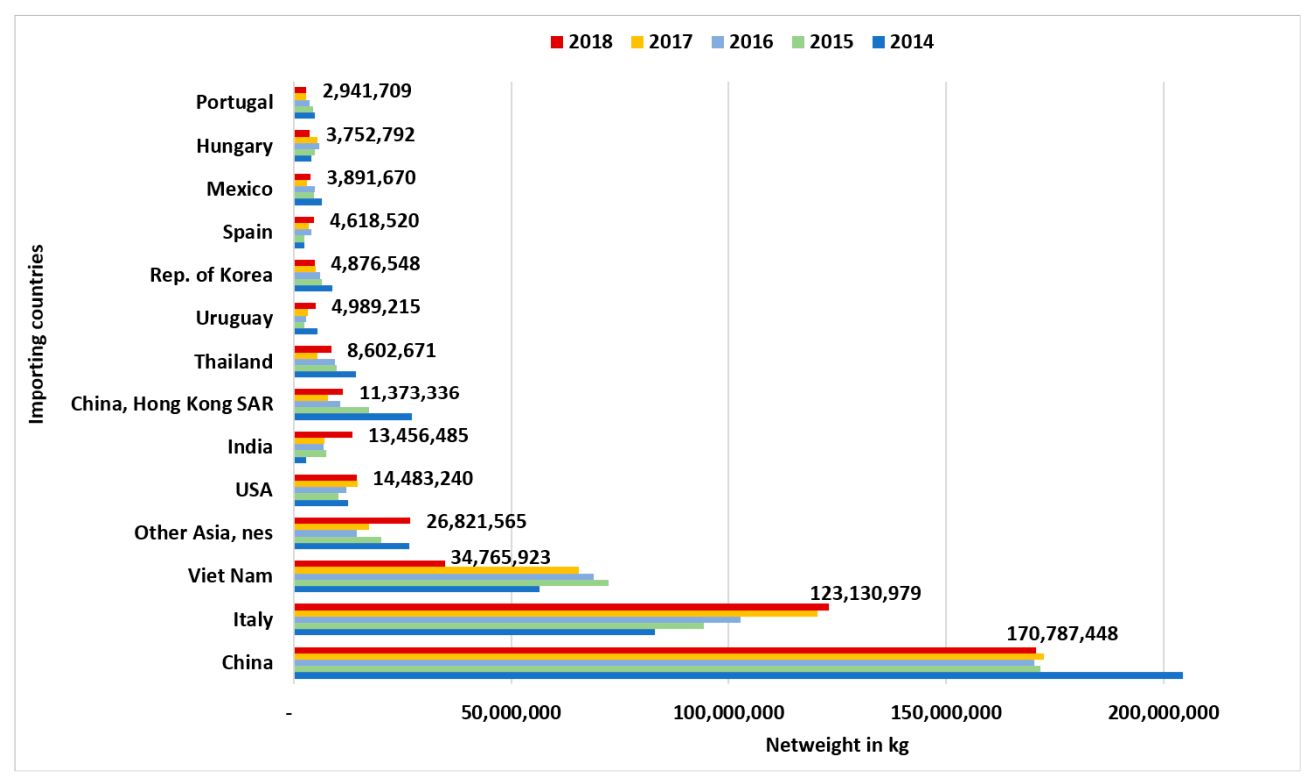

Figure 1. Top 15 countries importing Brazilian bovine hides and leather (HS 4101, 4104 and 4107 combined); net weight in $\mathrm{kg}$ [25]. Note that only the 2018 value labels are shown in the figure. 
The cross-check of data in terms of the top exporters of bovine hide and leather to Italy reveals similar results and reinforces the position of Brazil as an important source country. In 2018, Brazil's share among the top 10 exporting countries to Italy was $22 \%$. Brazil tops the list in terms of the sum of the net weight of the 4101, 4104 and 4107 product categories. While European countries remain as major sources of raw hides, Brazil is still on the top of the list for the wet-blue and finished leather categories. In 2018, 92\% of the Brazilian leather exports to Italy was in the form of wet-blue (Figure 2).

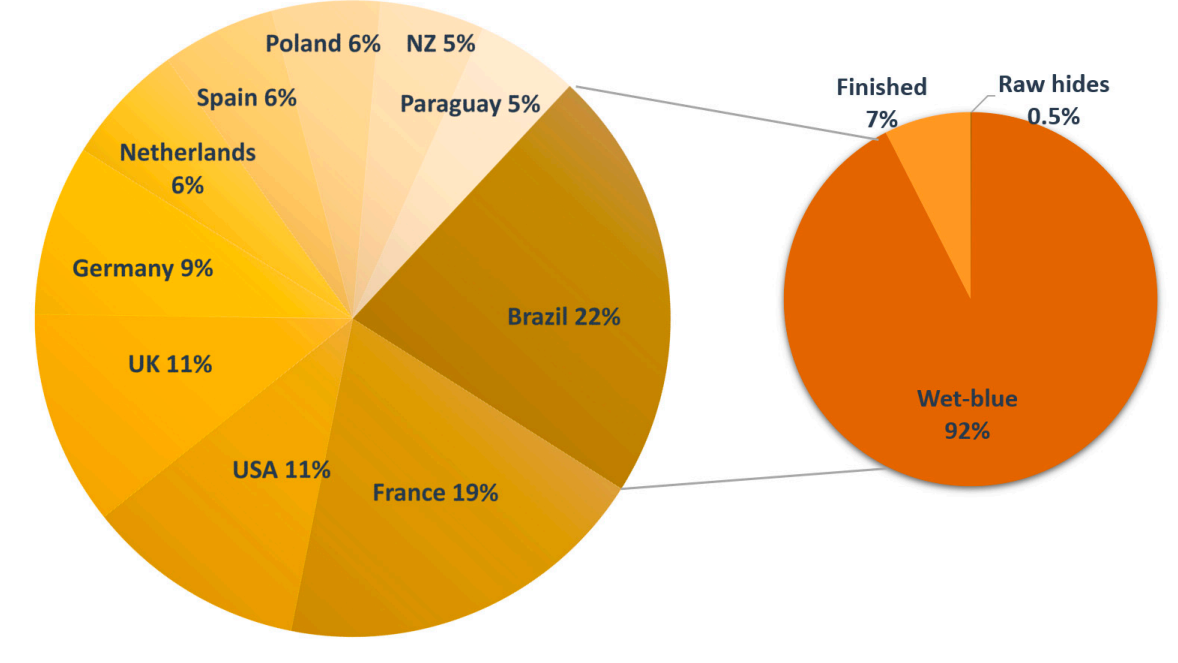

Figure 2. Top 10 Bovine hides and leather exporters to Italy in 2018 (as a \% of the total exported net weight in kilotons) and the share of raw hides, wet-blue and finished leather exported by Brazil to Italy in 2018 [25].

Due to technical difficulties and the long travel distance, but mostly due to the protectionist policies by the Brazilian government, Italy does not import raw (salted) hides from Brazil. The main reason behind the protectionism policy is to promote the Brazilian leather sector and to increase the share of value-added processes implemented within the country [43]. The Brazilian raw hides that get exported are mainly destined to Uruguay or China (Figure 3). However, this trend is likely to change in the future. Recently, Mercosur and the EU finalized an agreement, as part of the Free Trade Agreement, to liberalize the export of raw animal hides from Mercosur countries, including Brazil, to the EU [44].

The wet-blue (HS 4104) exports made up 41\% of Brazilian leather exports in 2018. Italy is the second-largest importer of Brazilian wet-blue hides, worth around 165 million USD in value. Regarding finished leather (HS 4107) exported from Brazil in 2018 (59\% of total leather exports), Italy is the number third importer in the list (82 million USD), following the United States of America (USA) (239 million USD) and China (88 million USD) (Figure 3). Thus, the share of the Italian market is especially important for wet-blue (semi-processed) leather exports.

\subsubsection{State-Level Leather Trade between Brazil and Italy}

Brazil is a federal country with twenty-six states and one federal district. The location of the livestock and slaughterhouses and export capacity by state is a fundamental component of the value chain organization. It is important to understand where within the national borders of Brazil the different categories of leather originate: the data on subnational, state or municipal origin are proxies of the exposure risk of certain destination markets to deforestation. As also demonstrated by Godar et al. [38,39], the exposure of European soy imports to deforestation risk increases when looked at the municipal and state level compared to the national-level estimations. By looking at the subnational-level data, Ermgassen et al. [45] found that most of the deforestation risk is associated with the domestic beef market in Brazil, as significant beef exporters are post-frontier and consolidated 
regions with a significant distance from the frontier deforestation. It is worth mentioning that around $80 \%$ of the produced beef is consumed locally in Brazil, while the export trends for bovine leather is the opposite. Thus, deforestation risk can be considered more embedded in leather exports compared to beef.

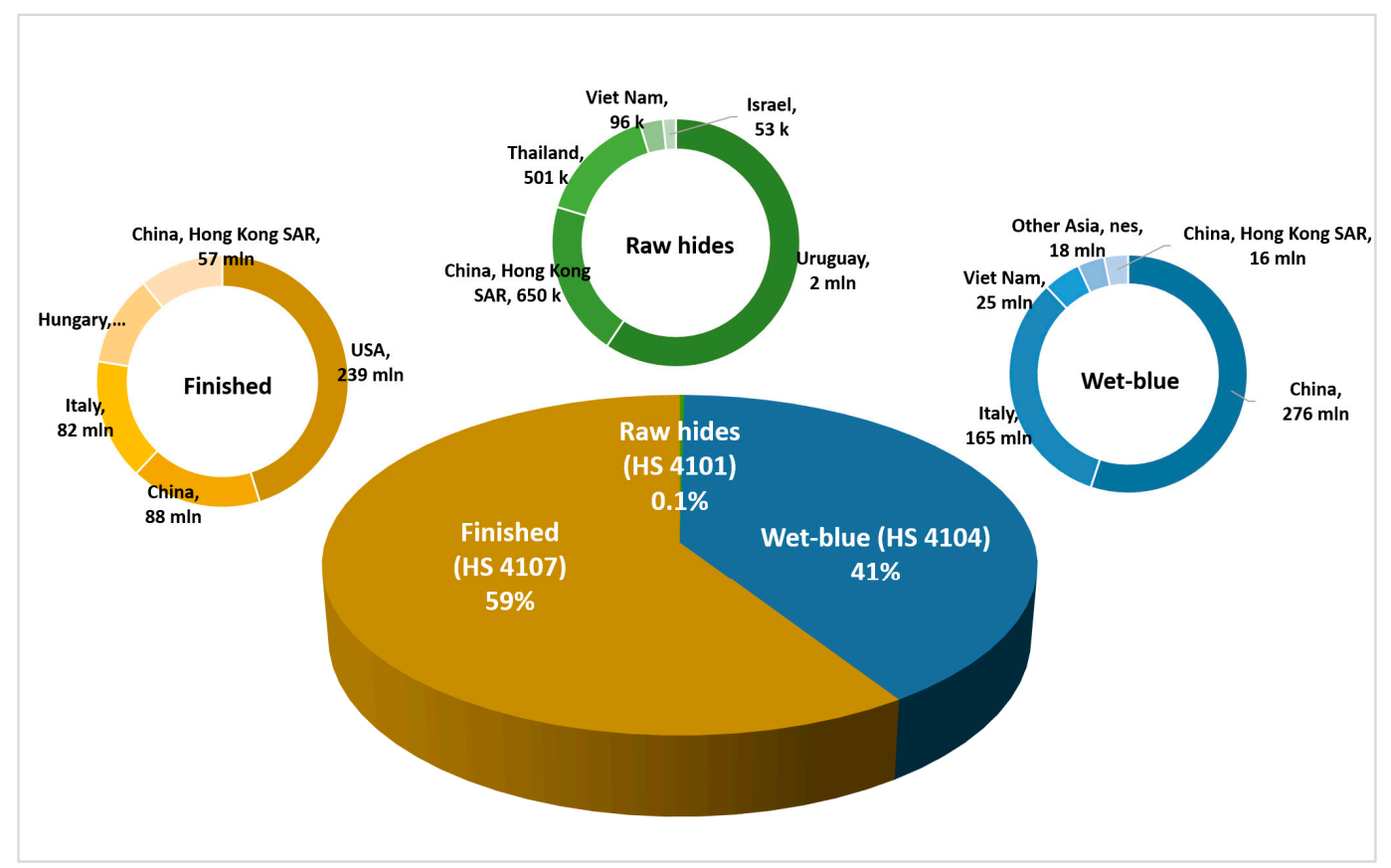

Figure 3. The share of raw (salted) hides, wet-blue and finished leather exported by Brazil in 2018 and the top 5 importers of each HS product category in 2018, in USD [25].

The data on state-level exports represent the states where the leather is exported after being processed as opposed to indicating the origin of the leather. The tanneries located in the frontier states (that are usually near slaughterhouses) are specialized in the initial stages of leather treatment from raw hides till wet-blue [46]. Long-distance transportation of leather in the salted and wet-blue stage is also more convenient due to diverse technical and logistical reasons. If not directly exported to foreign countries, wet-blue leather originating from the BLA states is transported to the southern and south-eastern states of Brazil where leather tanning and manufacturing has historically been an important economic activity and where know-how and tannery associations also concentrate [42]. One of the reasons why the export statistics for the southern and south-eastern states appear higher in volume is the mentioned interstate trade within Brazil.

Figure 4 shows that in terms of total exports (i.e., by considering all three HS categories combined), the BLA states Mato Grosso, Pará, Tocantins, and Amazonas are among the top 10 exporting states to Italy. The state of Amazonas started appearing as an exporter to Italy since 2018. It is worth noting that within the BLA these states also have the largest share of accumulated deforestation throughout 2008-2018: Pará (41\%), Mato Grosso (20\%) and Amazonas (10\%) [13]. Amazonas also declared an emergency over the recent forest fires, which surged as the result of increased illegal deforestation, in August 2019 [47].

In 2018, around 10\% (15 million USD net value) of Italy's imports of semi-processed (HS 4104) leather (i.e., wet-blue) came directly from the BLA region. Pará, the state with the higher level of deforestation, exported almost half (7 million USD in value) of the total wet-blue exports to Italy, although the major export market for Pará was China (Table 1). 


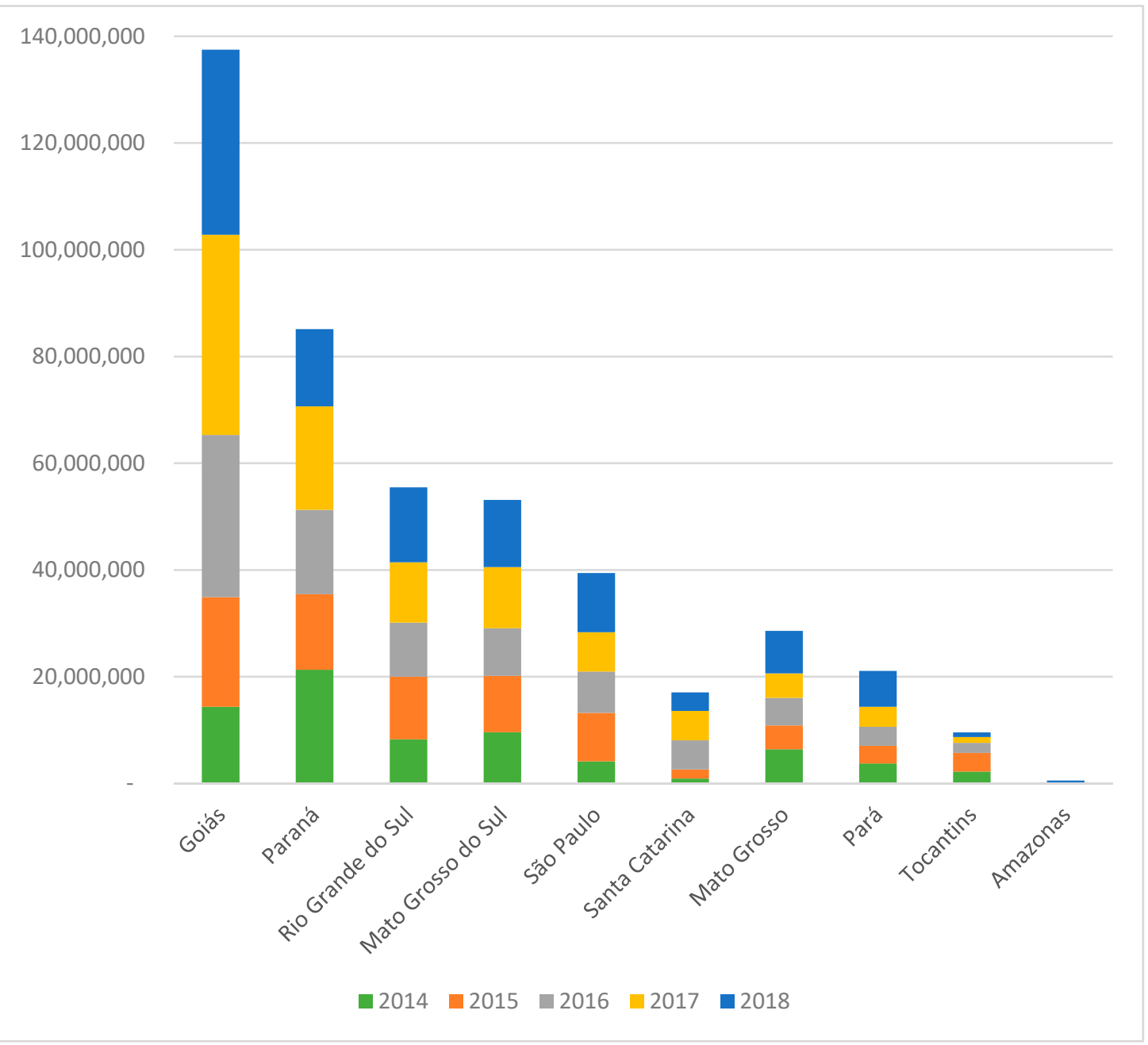

Figure 4. Top 10 Brazilian states exporting to Italy in the period 2014-2018; net weight in kg [48].

Table 1. Wet-blue exports from the Pará state in 2018, in net value (USD), net weight (kg) and percentages relative to the grand total. [48].

\begin{tabular}{ccccc}
\hline $\begin{array}{c}\text { Destination } \\
\text { Countries }\end{array}$ & $\begin{array}{c}\text { Sum of 2018-Value } \\
\text { Free on Board (FOB) } \\
\text { (USD) }\end{array}$ & $\begin{array}{c}\text { Percentage of } \\
\text { Grand Total in } \\
\text { Value }\end{array}$ & $\begin{array}{c}\text { Sum of 2018-Net } \\
\text { Weight (kg) }\end{array}$ & $\begin{array}{c}\text { Percentage of } \\
\text { Grand Total in } \\
\text { Net Weight }\end{array}$ \\
\hline China & $22,512,774$ & $69.7 \%$ & $13,971,345$ & $67.6 \%$ \\
Italy & $7,343,160$ & $22.7 \%$ & $5,051,382$ & $24.5 \%$ \\
Portugal & 784,955 & $2.4 \%$ & 389,760 & $1.9 \%$ \\
Spain & 567,634 & $1.8 \%$ & 356,380 & $1.7 \%$ \\
Dominican & 366,945 & $1.1 \%$ & 274,263 & $1.3 \%$ \\
Republic & 239,883 & $0.7 \%$ & 143,149 & $0.7 \%$ \\
Vietnam & 152,777 & $0.5 \%$ & 251,092 & $1.2 \%$ \\
India & 92,658 & $0.3 \%$ & 59,790 & $0.3 \%$ \\
Hong Kong & 84,640 & $0.3 \%$ & 39,100 & $0.2 \%$ \\
Japan & 76,236 & $0.2 \%$ & 58,960 & $0.3 \%$ \\
Thailand & 75,948 & $0.2 \%$ & 41,520 & $0.2 \%$ \\
Taiwan (Formosa) & 20,020 & $0.1 \%$ & 20,220 & $0.1 \%$ \\
Estonia & $32,317,630$ & $99.9 \%$ & $20,656,961$ & $99.9 \%$ \\
\hline Grand total & & &
\end{tabular}

With reference to finished leather (HS 4107), Mato Grosso appears as the only direct exporting state among all the BLA states in 2018 (Table 2). This can be explained by the fact that the cattle, as well as the leather industry is more consolidated in this state compared to the much newer frontiers, such as Pará or Amazonas [49]. Italy ranks fifth among the destination countries in terms of value and 
volume. The rest of the Brazilian finished leather is exported from the southern, south-eastern and eastern Brazilian states, where the leather industry is more consolidated.

Table 2. Exports of finished leather (HS 4107) from the state of Mato Grosso in 2018, in Free on Board (FOB) value (USD), net weight in $\mathrm{kg}$ and percentages relative to the grand total [48].

\begin{tabular}{ccccc}
\hline $\begin{array}{c}\text { Destination } \\
\text { Countries }\end{array}$ & $\begin{array}{c}\text { 2018-Value } \\
\text { FOB (USD) }\end{array}$ & $\begin{array}{c}\text { Percentage of Grand } \\
\text { Total in Value }\end{array}$ & $\begin{array}{c}\text { 2018-Net } \\
\text { Weight (kg) }\end{array}$ & $\begin{array}{c}\text { Percentage of Grand } \\
\text { Total in Net Weight }\end{array}$ \\
\hline Mexico & $7,781,489$ & $48.2 \%$ & 485,406 & $27.7 \%$ \\
United States & $7,467,209$ & $46.3 \%$ & 399,080 & $22.8 \%$ \\
Netherlands & $7,102.79$ & $0.0 \%$ & 672,991 & $38.4 \%$ \\
Hong Kong & $1,313.82$ & $0.0 \%$ & 100,340 & $5.7 \%$ \\
Italy & 879,505 & $5.4 \%$ & 92,325 & $5.3 \%$ \\
Canada & 7,906 & $0.0 \%$ & 332 & $0.0 \%$ \\
\hline Grand total & $16,144,526$ & $99.9 \%$ & $1,750,474$ & $99.9 \%$ \\
\hline
\end{tabular}

\subsubsection{Exporter-Importer-Level Leather Trade between Brazil and Italy}

Customs data for the year 2018 allow tracking major transactions in terms of leather trade between Brazil and Italy. Both in terms of exporters (shippers) from Brazil and importers (consignees) of the hides and leather, the major share is handled not by tanneries themselves but by logistics companies or intermediaries. Crossmatch of the customs data on both sides shows that the biggest consignee on the Italian side, Mar VI Speed SRL Spedizioni Internazionali, is also a major client of the biggest exporting company on the Brazilian side, Euro America International Freight Forwarders. Although the mentioned importing logistics company has offices all over Italy, one of the major shipping centers is located in the Arzignano district in the Veneto region, north-east Italy [50]. Based on the convenient location of this company in the heart of the Arzignano district as well as triangulation through the information gathered from the website of the UNIC and through personal communications, we can infer that the majority of the Brazilian leather is imported by the Veneto region tanning district. As the district mainly serves upholstery and furniture markets, major clients of these tanneries face a risk that they could be purchasing leather from deforested lands in the Amazon. Brazilian leather is considered medium to low quality making it more suitable for the use mainly in furniture and car upholstery as opposed to the use in high-end fashion which usually turns to high-quality European leather.

\subsubsection{Final Destination of Italian Leather Products}

Figure 5 presents the top 12 importing countries of Italian exports of leather (raw, semi-processed and finished combined HS 41), articles of leather (HS 42) and leather footwear (HS 6403 and 6404) in 2018, in trade value (million USD). In all three categories, European markets have major shares. The leading position of Romania for the imports of the HS 41 category from Italy is due to the higher share of raw (salted) (HS 4101) and semi-processed leather (HS 4104). This could be explained by relatively lower labor cost, but also less strict environmental regulations around leather processing in Romania (the largest share of the environmental impact of leather processing tends to concentrate on the initial stages), as well as strong industrial and trade links among Romania and Italy, resulting from the delocalization of many Italian manufacturing activities in the past decades [51].

\subsection{Deforestation as the Legal and Reputational Risk}

The deforestation risk in the Brazilian leather supply chain can be categorized as mostly reputational and legal. Currently, actors at the beginning of the supply chain (e.g., farmers and slaughterhouses) can be described as more susceptible to regulatory risks and those further down in the supply chain (e.g., tanneries, manufacturers and retailers) to reputational risks. Besides legal and reputational risks, the leather supply chain can also be exposed to operational risk. Increased deforestation, the feedback loop of climate change, water shortage and altered rainfall patterns is affecting the availability of resources for all industries, including cattle farming in Brazil [52,53]. 


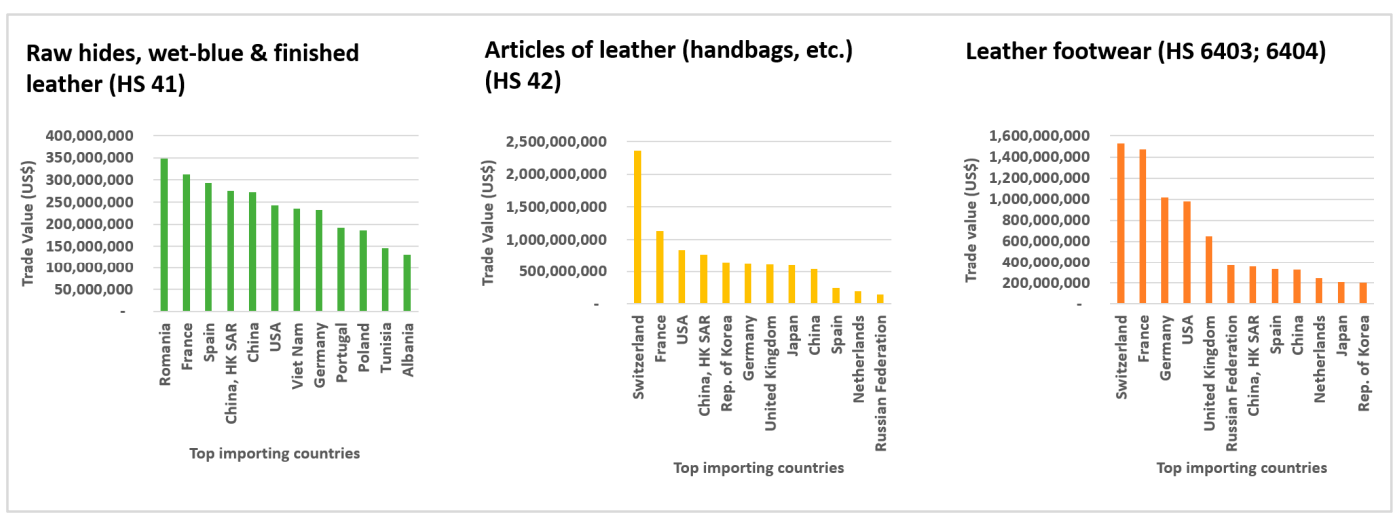

Figure 5. Top 12 country importers of Italian exports of leather (raw, semi-processed and finished combined HS41), articles of leather (HS 42) and leather footwear (HS 6403;6404) in 2018, in trade value USD [25].

\subsubsection{Reputational Risk}

After the publication of the reports "Slaughtering the Amazon" [54] and "Time to pay the bill" (Hora di Conta) [55], the discussion about deforestation risk in the leather supply chain became a topic of public debates, although mostly overshadowed by that of beef and soy as main drivers of deforestation. Following these reports and later claims by non-governmental organizations (NGOs), major brands such as Timberland, Clarks, Nike and Adidas (among others) put forward pledges to cut the trade relations with suppliers associated with deforestation [56]. Since then a number of other brands and manufacturers in the footwear, upholstery and furniture sectors that use leather extensively in their products have put forward deforestation-related commitments or started looking for alternative materials as substitutes. The recent coverage by the Supply Change initiative run by Forest Trends featured 29 such entities with commitments linked to leather [57]. Due to an exposed brand image in 2013, the major fashion brand Gucci started a pilot project of a line of "deforestation-free" bags. By getting access to hides originating from the Sustainable Agriculture Network (SAN)-Rainforest Alliance certified São Marcelo farm in Tangará da Serra, Mato Grosso state, the brand could act on its reputational risk. However, the project was discontinued afterward [58].

The recent investigation by Amazon Watch also claims that the slaughterhouse Frigorifico Redentor, a subsidiary of Grupo Bihl, involved in "Operation Abate" in 2009 and sanctioned with fines over illegal deforestation in the Mato Grosso state in 2017-2018, has supplied Veneto-based (north-east Italy) tanneries, such as the Rino Mastrotto Group (two shipments totaling 162 tons), Faeda (ten shipments totaling 483 tons), Conceria Cadore (four shipments totaling 219 tons), Conceria Cristina (five shipments totaling 99 tons) and Italpelli (thirteen shipments totaling 530 tons) in 2018 [30].

It is also possible to check for the BLA-based tanneries (municipality-level precision) involved in the trade with Italy by matching the list of exporting tanneries from the database of the company registries in Brazil [49] with their locations found via searches on Google Maps. The analysis of the customs data, as well as the Comexstat database registries show that Italy receives finished leather from the Pedra Preta Municipality in the Mato Grosso state. A Google Maps search reveals only one registered tannery within that municipality which is owned by JBS S.A. The company also owns a tannery in the Maraba municipality (one of the important deforestation frontiers) in the Pará state. The Comexstat database shows that Italy imports leather also from the Maraba municipality.

In the face of the recent forest fires in Brazil, some major global brands have taken the lead, announcing their concerns [59]. The VF Corporation officially announced a provisional ban on Brazilian leather until it could "... have the confidence and assurance that the materials used in [its] products do not contribute to environmental harm in the country" [60]. The major fast-fashion retailer H\&M has also declared a similar ban on Brazilian leather [61]. Car manufacturers BMW and Volkswagen have both also stated privately that sourcing sustainable leather is on their agenda [62]. Furniture retailer 
IKEA is working on extending its in-house traceability system to ensure that it sources from farms without deforestation risk.

The increased civil society pressure, public debates and corporate commitments gave rise to third-party initiatives that would help to add assurance to the deforestation-free leather claims. In 2010 the Leather Working Group (LWG) developed a Traceability Audit Protocol especially for the case of Brazil and Amazonian deforestation setting 2009 as a baseline year of deforestation [63]. The audits held by LWG against this protocol result in gold, silver, bronze or "audited" rates, depending on how successful the tannery is in tracing the origin of the hide till the slaughterhouse. The topic of deforestation and land-use change is also one of the important focuses of the Responsible Leather Round Table (RLRT), a more recent multi-stakeholder initiative started in 2018. Among many, it aims to help downstream market actors to make sustainability claims by participating in a credit trading system and purchasing sustainable farming credits put forward by farmers directly [64].

\subsubsection{Legal or Regulatory Risk}

Internationally, the discussions about leather as a forest-risk commodity mostly prevail in public policy documents that originated within the EU and discussed at the beginning of the paper. Leather is mentioned repeatedly in the study on embodied deforestation conducted by the EC although mostly in connection to beef $[4,41]$. The Amsterdam Declaration "Towards Eliminating Deforestation from Agricultural Commodity Chains with European Countries" of 2015 signed by seven European countries mention leather as a commodity sector with deforestation risk.

In Brazil, the leather industry has already faced and continues to face regulatory risks. First, the results of the latest audit published by Public Prosecutor Office of Pará in 2018 include a number of leather tanneries located in the state, sending out the signal that deforestation is a legality risk for the leather sector and that they are required to have a traceability system in place [65]. Secondly, recent scandals such as Carne Fria (Cold Meat), Carne Fraca (Weak Meat) and Lava Jato (Car Wash) that involved illegalities, respectively, in terms of purchasing cattle from illegally deforested areas, wide-spread bribery of officials to overlook the sale of spoiled meat and the biggest corruption scheme involving top-level politicians and businesses, have also impacted the leather industry. This impact was felt both at the reputational as well as regulatory level in the example of JBS, the biggest meatpacking company in Brazil and in the world, which consequently also controls a major share of the leather industry in Brazil $[66,67]$. These risks are passed further down to the leather industry.

Since 2018, Italy also started importing wet-blue leather from the state of Amazonas, a relatively new but rapidly increasing deforestation frontier state. A search on Google Maps shows that there is only one tannery registered in the Amazonas state, i.e., SMX Agroindustrial Ltd.a. An operation under the title Archimedes started in June 2019 by the Public Prosecutor Office of the Amazonas State includes an open investigation against SMX Agroindustrial Ltd.a over environmental crimes [68].

The most recent political events in Brazil and the lenient approach of the current government of Brazil towards legal and illegal deforestation in the country are increasing all the risk components associated with leather production and trade. The current government's plans include opening up more forest areas in the northern states for agriculture production, road construction, hydroelectric dams and connecting those areas with big commercial centers of the country and around the world. The current government's actions are directed towards weakening environmental protections and dismantling environmental agencies [69,70]. Due to an increased feeling of impunity, the deforestation within BLA has increased dramatically, and just in June 2019 alone, deforestation has increased by $88 \%$ compared to the same month of the last year $[10,71]$. These new developments bring another level of risk for businesses, and the political regime-related risks should be differentiated from conventional regulatory or legality risks. 


\section{Discussion}

The European market is one of the major destinations for Brazilian forest-risk commodities, ranging from agricultural to mining-based raw material. The role of trade and finance as an underlying driver of deforestation and forest degradation has been studied for many years and now emphasized even more due to the EU-Mercosur Free Trade Agreement. In the leather sector, the openness to trade brought by this deal is already reflected through the fact that it will allow the export of raw (salted) bovine hides from Brazil to Europe, including Italy [44].

By bringing together the analysis of embedded deforestation in trade together with the one in the leather supply chain-as a non-conventional commodity sector to look for the risk-we analyzed how the deforestation risk appears at many different levels. Trade data analysis helps to link commodity production sites to the markets where those commodities are consumed with the aim to support the gradual shift of responsibility of deforestation to developed country markets instead of being discarded as solely a governance problem of developing countries. Depending on the granularity of the analysis, i.e., whether the national, state or importer-exporter level data is analyzed, the linkage between risky production sites and the consumer markets and, consequently, the visibility of the risk, can differ. Looking at the data at the state or municipality level, rather than at the total national level, helps to even more closely connect the European and Italian markets with the deforestation frontiers. Following individual company supply chains and associated illegalities shows that the topic also needs to be addressed case-by-case.

In this regard, municipality and individual exporter level trade data analysis helps to better understand and trace the deforestation risk in Brazilian-Italian leather trade, compared to national and even state level export data. As mentioned previously, leather (once it is salted) is a commodity that has much higher mobility and longer shelf time compared to beef. Due to this mobility and flexibility allowed through the exemption of sanitary checks (necessary for the beef market), leather travels easily among Brazilian states as well as internationally. The BLA states with most of the continuous deforestation are also the ones with less consolidated infrastructure for leather processing. Leather processed until the wet-blue stage (HS 4104) is either exported directly from those states to other countries or sent southwards to the other Brazilian states where most of the infrastructure for further processing is located. Due to this interstate trade and difficulty accessing data on this type of transactions, the extent of the deforestation risk in the Brazilian-Italian leather trade is difficult to quantify. Besides, the origin of the leather and traceability can get lost once it reaches Italy in a semi-processed form (HS4104). Most of the Italian imports of Brazilian leather are in a semi-processed form (i.e., wet-blue), which can be declared as leather made in Italy after certain final processing conducted in Italy, according to the Italian Standard UNI 11239 [72].

In the light of data shortage and inconsistencies, the concept of embedded deforestation is more suitable to discuss in the context of the leather supply chain compared to the physical footprinting of the deforestation $[4,22,73]$. This latter kind of analysis would require more detailed and quantifiable data across time and locations. Besides, the existing methodologies on environmental footprinting assume that the original forest cover is cleared to make the way to produce certain commodities by looking at direct causal links. Although very useful to analyze the concept of deforestation risk, these methodologies still need to evolve to include embedded deforestation as a comprehensive concept that was addressed through this research. Embedded deforestation is difficult to measure, a problem that is reflected in the fact that major policy documents and scientific research focus on analyzing deforestation risk of a small, selected number of forest-risk commodities [41,42]. Although, this type of analysis is more pragmatic and can deliver quantifiable results to guide decision-making; for conceptualizing deforestation along the supply chains and understanding the politics of responsibility, a broad understanding of embedded deforestation has certain benefits.

At this point, it is important to note that according to customs data, some major Italian banks appear as consignees for around $1 \%$ of the total imported Brazilian leather within the period August 2017-2018. Although corresponding to a negligible percentage of total imports, this data helps start 
the discussion about the embedded deforestation due to the leather sector also in bank transactions and investments. Analysis of consistent data for a longer period could reveal more statistically significant results.

\section{Conclusions}

This paper presents the results of trade data analysis for leather between Brazil and Italy. The analysis helps to demonstrate that, despite the largely claimed statement by the Italian tanneries, Italy does import from deforestation frontier states, whether it is in the form of direct flows from BLA states to Italy or through re-exports from the southern and south-eastern states. Thus, the Italian leather trade with Brazil possesses the risk of Amazonian deforestation, unless the proper traceability and due diligence systems are in place to claim the opposite. Although bovine leather cannot be attributed as a direct driver of deforestation, its supply chains are still exposed to deforestation risk. The European and Italian leather industry need to be more proactive by acknowledging the existence of the deforestation risk, putting full traceability systems in place and sending out clear market signals that deforestation is not tolerated, and that sustainability is valued. The traceability should also go hand-in-hand with engagement, involving the upstream actors (farmers and slaughterhouses) in fair sharing of market benefits and sustainability costs.

While deforestation risk analysis and trade data focus on individual supply chains, embedded deforestation connects different product supply chains and looks at the impacts in the light of their interactions. Conducting trade data analysis and qualitative analysis of the risk for due diligence purposes through individual importer-exporter-related data helps to re-affirm the risk. The political analysis of responsibility and visibility helps to move beyond technical analysis of market interactions and add a human aspect to it with the aim to achieve both deforestation-free as well as socially just and fair supply chains [20].

When it comes to policies on avoiding embedded deforestation in imports, the EU needs to conduct more research on the topic but also act upon the results of the research with follow-up tangible policies. In many aspects, the EU is still a trailblazer and a global leader in promoting sustainability. This creates a very effective precedent for other countries and regions to follow. On the other hand, scattered policy-making also produces scattered results and weakens the impacts of one policy through the other one. While the EU sets up policy guidance documents and reports on the environmental impacts or deforestation footprint of its imports, on the other front it already (almost) ratifies a trade deal (EU-Mercosur Free Trade Agreement) that is a legally binding document and potentially detrimental to the environment. In this regard, a European Green Deal could serve as an important umbrella strategy to ensure coordination of the polices in different sectors that can potentially impact world forests [74]. Besides, the European Union Commission's Communication on Stepping up EU Action to Protect and Restore the World's Forests [41] is a good opportunity for common action that could lead to an EU-wide corporate due diligence mechanism to ensure legality and sustainability, instead of relying solely on voluntary commitments and private standards [75,76]. These efforts could enhance the effects of the policies aiming at reducing commodity-driven deforestation [77]. Currently, most of the documents related to embedded deforestation remain in the form of studies and not legally binding action plans. Thus, the EU needs to put more tangible efforts into achieving the pledge of halting global deforestation by 2020 [78].

Author Contributions: Conceptualization, A.M, M.M., D.P; investigation, A.M.; writing-original draft preparation, A.M.; writing-review and editing, A.M., M.M., D.P. All authors have read and agreed to the published version of the manuscript.

Funding: This research received no external funding.

Acknowledgments: We wish to thank the Global Canopy for sharing the customs trade data on leather exports from Brazil.

Conflicts of Interest: The authors declare no conflict of interest. 


\section{Appendix A. Additional Information about the Italian Leather Industry}

The leather industry in Italy is comprised of (i) tanneries (full cycle, wet-blue processors and crust processors); (ii) sub-contractors, such as dryers, millers, buffers, printers and supporting industries, such as tanning machinery, chemicals, logistics and depuration; and (iii) manufacturers transforming finished leather to different leather products. Traditionally the leather sector is made-up of small and medium enterprises that, like for other industrial or manufacturing sectors in Italy (e.g., tissue paper, furniture, etc.), are concentrated in districts for the purpose of benefiting from synergies, horizontal and vertical integration, sharing of technological know-how, artisanal knowledge and cost-efficient operations. These districts have developed into distinct territories shaping the landscape and identity of many areas. The main four industrial districts of the leather sector are as follows:

- Arzignano and Chiampo valley from Crespadoro to Montebello, from Montorso to Zermeghedo and Montecchio Maggiore (Vicenza, Veneto-north-east Italy);

- Santa Croce Sull'Arno and Ponte a Egola (Pisa, Tuscany—center-west Italy);

- Solofra (Avellino, Campania-south Italy);

- Turbigo (Milan, Lombardy—north-west Italy).

While tanneries based in Veneto mainly serve the furniture and automotive sectors, those based in Tuscany process medium- and small-sized cowhides for high fashion brands (mainly footwear and leather accessories) and those based in Campania are specialized in preparing hides for clothing and leather goods. These industrial districts make up 55\%, 28.5\%, 7.6\% and 5\% of the total Italian leather production value, respectively. The Italian tanning industry employs in total 17,612 people in around 1210 companies with an annual turnover of 5 billion euros (Figure A1) $[79,80]$.

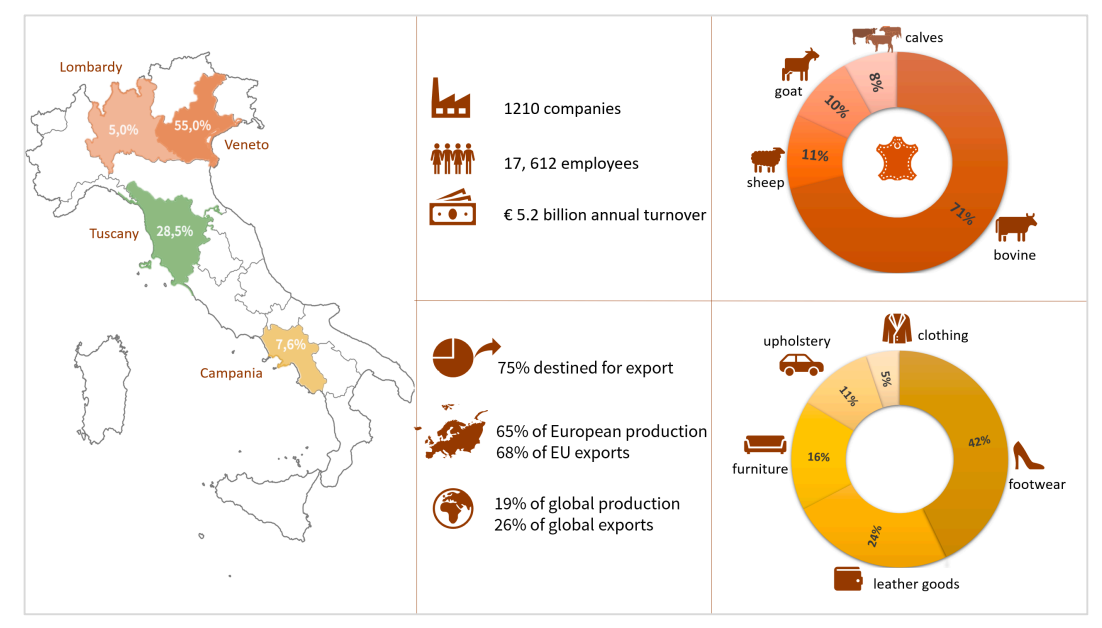

Figure A1. Italian leather industry in a nutshell [80].

A total of $90 \%$ of the processed raw materials are imported from other countries under the form of raw hides (mainly from the EU region, $52 \%$ ), wet-blue (47\%) and semi-finished products (crust, $1 \%$ ). With reference to exports, the Italian leather industry makes up around $65 \%$ of the total EU production and $20 \%$ of the total tanning industry turnover worldwide [79]. Around $75 \%$ of the Italian production value is exported, constituting $68 \%$ of the EU and $26 \%$ of world exports in total. The EU region is the main destination (51\%), followed by China, including Hong Kong (16\%), and the US (14\%).

Since 1946 the Italian leather industry has self-organized in the form of an association with the purpose of promoting the strategic interests of the industry in a much more organized form. Currently, 161 out of the 1210 companies are members of the Italian Tanners Association (Unione Nazionale Industria Conciaria, UNIC). UNIC is also a member of The Confederation of National Associations of Tanners and Dressers of the European Community (Cotance) and of the International Council of Tanners (ICT) [79]. 
Appendix B.

Table A1. The list of the Harmonized Commodity Description and Coding Systems (HS) applicable to the case of bovine leather [25].

\begin{tabular}{|c|c|c|c|c|c|c|c|}
\hline \multirow{3}{*}{ HS2 } & \multirow{3}{*}{\multicolumn{4}{|c|}{ 41-43. Raw Hides, Skins, Leather, \& Furs }} & \multicolumn{3}{|c|}{ 41. Raw hides and skins (other than fur skins) and leather } \\
\hline & & & & & \multicolumn{3}{|c|}{ 42. Articles of leather; saddlery and harness; travel goods, handbags and similar containers; articles of animal gut (other than silk-worm gut) } \\
\hline & & & & & \multicolumn{3}{|c|}{ 43. Fur skins and artificial fur; manufactures thereof } \\
\hline HS2 & Description & HS4 & Description & HS6 & Description & HS8 & Description \\
\hline \multirow{23}{*}{41} & \multirow{23}{*}{$\begin{array}{l}\text { Raw hides and } \\
\text { skins (other than } \\
\text { fur skins) and } \\
\text { leather }\end{array}$} & \multirow{23}{*}{4101} & \multirow{23}{*}{$\begin{array}{l}\text { Raw hides and skins of } \\
\text { bovine (including buffalo) } \\
\text { or equine animals s fresh, or } \\
\text { salted, dried, limed, pickled } \\
\text { or otherwise preserved, but } \\
\text { not tanned, } \\
\text { parchment-dressed or } \\
\text { further prepared), whether } \\
\text { or not dehaired or split }\end{array}$} & 410110 & Raw skins of bovine, whole, when dried $<=8 \mathrm{~kg}$, etc. & 41011000 & Raw skins of bovine, whole, when dried $<=8 \mathrm{~kg}$, etc. \\
\hline & & & & \multirow{4}{*}{410120} & \multirow{4}{*}{$\begin{array}{l}\text { Whole raw hides and skins of bovine incl. buffalo or equine animals, whether or not dehaired } \\
\text { or split, of a weight per skin }<=8 \mathrm{~kg} \text { when simply dried, }<=10 \mathrm{~kg} \text { when dry-salted, or }<=16 \\
\mathrm{~kg} \text { when fresh, wet-salted or otherwise preserved (excl. tanned and pa }\end{array}$} & 41012000 & Raw hides and skins, whole, with weight restriction \\
\hline & & & & & & 41012010 & Whole leathers/skin of bovine, $\mathrm{n} /$ divided $\mathrm{w}<=8 \mathrm{~kg}$ \\
\hline & & & & & & 41012020 & Divid./whol.leathers/skin, bovine, grain splits, $\mathrm{w}<=8 \mathrm{~kg}$ \\
\hline & & & & & & 41012030 & Divid./whol.leat.//kin, bovine, splits(than grain)w $<=8 \mathrm{~kg}$ \\
\hline & & & & \multirow{3}{*}{410121} & \multirow{3}{*}{ Whole hides and skins of bovine animals (fresh or wet-salted) } & 41012110 & Raw skins of bovine, whole, $\mathrm{n} /$ divided, fresh, etc. \\
\hline & & & & & & 41012120 & Raw skins of bovine, whole, grain splits, fresh, etc. \\
\hline & & & & & & 41012130 & Raw skins of bov. whole, splits(than grain spl.)fresh, etc. \\
\hline & & & & \multirow{3}{*}{410122} & \multirow{3}{*}{ Buttes and bends (skins of bovine animals) } & 41012210 & Raw skins of bovine, (backs), not slipt, fresh, etc. \\
\hline & & & & & & 41012220 & Raw skins of bovine, (backs), grain splits, fresh, etc. \\
\hline & & & & & & 41012230 & Raw skins of bovine, (backs), slipts (than grain) fresh, etc. \\
\hline & & & & \multirow{6}{*}{410129} & \multirow{6}{*}{ Other hides and skins of bovine animals (fresh or wet-salted) } & 41012910 & Oth. raw skins of bov.(backs), n/slipt, fresh, etc. \\
\hline & & & & & & 41012920 & Oth. raw skins of bovine, (backs), grain splits, fresh, etc. \\
\hline & & & & & & 41012930 & Ot. raw skins of bovine, slipts(than grain spl.)fresh, etc. \\
\hline & & & & & & 41013010 & Raw skins of bovine, conser.of another way, not slipt \\
\hline & & & & & & 41013020 & Raw skins, of bovine, conser.of another way, grain splits \\
\hline & & & & & & 41013030 & Raw skins of bovine, cons.another way slipts (than grain) \\
\hline & & & & \multirow{3}{*}{410150} & \multirow{3}{*}{$\begin{array}{l}\text { Whole raw hides and skins of bovine incl. buffalo or equine animals, whether or not dehaired } \\
\text { or split, of a weight per skin }>16 \mathrm{~kg} \text {, fresh, or salted, dried, limed, pickled or otherwise } \\
\text { preserved (excl. tanned, parchment-dressed or further prepared) }\end{array}$} & 41015010 & Whole leathers/skin of bovine, not split, $\mathrm{w}<=16 \mathrm{~kg}$ \\
\hline & & & & & & 41015020 & Whole leathers/skin, bovine, grain splits, $\mathrm{w}<=16 \mathrm{~kg}$ \\
\hline & & & & & & 41015030 & Whole leath./skin, bov. slipts (ot. than grain sp.), $\mathrm{w}<=16 \mathrm{~kg}$ \\
\hline & & & & \multirow{3}{*}{410190} & \multirow{3}{*}{$\begin{array}{l}\text { Butts, bends, bellies and split raw hides and skins of bovine incl. buffalo or equine animals, } \\
\text { whether or not dehaired, fresh, or salted, dried, limed, pickled or otherwise preserved, and } \\
\text { whole raw hides and skins of a weight per skin }>8 \mathrm{~kg} \text { but }<16 \mathrm{~kg} \text { w }\end{array}$} & 41019010 & Other leathers/skin, bovine, not split \\
\hline & & & & & & 41019020 & Other leathers/skin, of bovine, grain splits \\
\hline & & & & & & 41019030 & Raw skins of bovine, cons. another way slipts (than grain) \\
\hline
\end{tabular}


Table A1. Cont.

\begin{tabular}{|c|c|c|c|c|c|c|c|}
\hline \multirow{3}{*}{ HS2 } & \multirow{3}{*}{\multicolumn{4}{|c|}{ 41-43. Raw Hides, Skins, Leather, \& Furs }} & \multicolumn{3}{|c|}{ 41. Raw hides and skins (other than fur skins) and leather } \\
\hline & & & & & \multicolumn{3}{|c|}{ 42. Articles of leather; saddlery and harness; travel goods, handbags and similar containers; articles of animal gut (other than silk-worm gut) } \\
\hline & & & & & \multicolumn{3}{|c|}{ 43. Fur skins and artificial fur; manufactures thereof } \\
\hline HS2 & Description & HS4 & Description & HS6 & Description & HS8 & Description \\
\hline & & & & \multirow{5}{*}{410410} & \multirow{5}{*}{ Whole bovine skin leather } & 41041011 & Leathers/skin whole, bovine, $\mathrm{s}<=2.6 \mathrm{~m}^{2}$, "wet blue", $\mathrm{n} / \mathrm{spl}$ \\
\hline & & & & & & 41041012 & Leathers/skin whole, bovine, $\mathrm{s}<=2.6 \mathrm{~m}^{2}$, "wet blue", grain sl \\
\hline & & & & & & 41041013 & Leathers/skin whole, bov.s $<=2.6 \mathrm{~m}^{2}$, "wet blue", splitsthan \\
\hline & & & & & & 41041020 & Leathers/skin whole, bovine, $\mathrm{s}<=2.6 \mathrm{~m}^{2}$, "box-calf" \\
\hline & & & & & & 41041090 & Oth. leathers/skins whole, bovine, $\mathrm{s}<=2.6 \mathrm{~m}^{2}$, prepared \\
\hline & & \multirow{26}{*}{4104} & \multirow{26}{*}{$\begin{array}{c}\text { Tanned or crust hides and } \\
\text { skins of bovine (including } \\
\text { buffalo) or equine animals, } \\
\text { without hair on, whether or } \\
\text { not split, but not further } \\
\text { prepared }\end{array}$} & \multirow{8}{*}{410411} & \multirow{8}{*}{$\begin{array}{l}\text { Full grains, unsplit and grain splits, in the wet state incl. wet-blue, of hides and skins of } \\
\text { bovine incl. buffalo or equine animals, tanned, without hair on (excl. further prepared) }\end{array}$} & 41041111 & Whole leathers of bovines, $\mathrm{n} / \mathrm{split}$ "wet blue", $\mathrm{s}<=2.6 \mathrm{~m}^{2}$ \\
\hline & & & & & & 41041112 & Whole leath. of bovines, slipts (than grain split) $<=2.6 \mathrm{~m}^{2}$ \\
\hline & & & & & & 41041113 & Oth. leathers of bovines, $\mathrm{n} / \mathrm{slipt}$ wet pre-tanned, veg. \\
\hline & & & & & & 41041114 & Oth. leathers bovines, incl. buffalos, wet split(than grain \\
\hline & & & & & & 41041121 & Whole leathers of bovine, split" wet blue", $\mathrm{s}<=2.6 \mathrm{~m}^{2}$ \\
\hline & & & & & & 41041122 & Whole leathers of bovines, grain splits s $<=2.6 \mathrm{~m}^{2}$ \\
\hline & & & & & & 41041123 & Oth. tanned bovine, split, wet, veget pre-tanned \\
\hline & & & & & & 41041124 & Other leathers bovines, incl. buffalos, wet, grain splits \\
\hline & & & & \multirow{4}{*}{410419} & \multirow{4}{*}{$\begin{array}{l}\text { Hides and skins of bovine incl. buffalo or equine animals, in the wet state incl. wet-blue, } \\
\text { tanned, without hair on, whether or not split (excl. further prepared and full grains, unsplit } \\
\text { and grain splits) }\end{array}$} & 41041910 & Other whole leathers of bovines, "wet blue", $\mathrm{s}<=2.6 \mathrm{~m}^{2}$ \\
\hline & & & & & & 41041920 & Oth. leathers/skins, whole, bovines, wet states $<=2.6 \mathrm{~m}^{2}$ \\
\hline & & & & & & 41041930 & Oth. leathers/skins, bovines, wet state veg.pre-tanned \\
\hline & & & & & & 41041940 & Other leathers/skins, bovines, including buffalos, wet \\
\hline & & & & 410421 & Leathers/skins, bovines, vegetable pre-tanned & 41042100 & Leathers/skins, bovines, vegetable pre-tanned \\
\hline & & & & \multirow{5}{*}{410422} & \multirow{5}{*}{ Bovine leather (otherwise pre-tanned) } & 41042211 & Leathers/skins, whole/half, bovines, wet blue, $\mathrm{n} /$ split \\
\hline & & & & & & 41042212 & Leathers/skins, whole/half, bovines, wet blue, grain split \\
\hline & & & & & & 41042213 & Leathers/skins, whole/half, bovines, wet blue, split (than g \\
\hline & & & & & & 41042219 & Other leathers/skins, bovines, "wet blue" \\
\hline & & & & & & 41042290 & Oth. leathers, bovines, pre-tanned of other way \\
\hline & & & & 410429 & Other leathers/skins, of bovines/equine, tanned or retanned & 41042900 & Oth. leathers/skins, of bovines/equine, tanned or retanned \\
\hline & & & & \multirow{4}{*}{410431} & \multirow{4}{*}{ Other bovine leather and equine leather (full grains and grain splits) } & 41043111 & Leat./skins, bovin.veg.pre-tann. for soles, grain split n/fi \\
\hline & & & & & & 41043119 & Ot.leat./skins, bov.pre-tan.prepar.grain split n/finis. \\
\hline & & & & & & 41043120 & Leat./skins, bov.after tann.prepar.grain split n/finis. \\
\hline & & & & & & 41043190 & Ot. leat./skins, bov./equine pre-tan. prepar. grain split \\
\hline & & & & \multirow{3}{*}{410439} & \multirow{3}{*}{ Other bovine leather and equine leather (parchment-dressed) } & 41043911 & Ot. leat./skins, bovine after-tann. prepar. n/finishing \\
\hline & & & & & & 41043912 & Ot.leat./skins, bovine, after-tann. prepar. with finishing \\
\hline & & & & & & 41043990 & Oth. leath./skins, bovine/equine, parchment-dressed \\
\hline
\end{tabular}


Table A1. Cont.

\begin{tabular}{|c|c|c|c|c|c|c|c|}
\hline \multirow{3}{*}{ HS2 } & \multirow{3}{*}{\multicolumn{4}{|c|}{ 41-43. Raw Hides, Skins, Leather, \& Furs }} & \multicolumn{3}{|c|}{ 41. Raw hides and skins (other than fur skins) and leather } \\
\hline & & & & & \multicolumn{3}{|c|}{ 42. Articles of leather; saddlery and harness; travel goods, handbags and similar containers; articles of animal gut (other than silk-worm gut) } \\
\hline & & & & & \multicolumn{3}{|c|}{ 43. Fur skins and artificial fur; manufactures thereof } \\
\hline \multirow[t]{15}{*}{ HS2 } & \multirow[t]{15}{*}{ Description } & \multirow[t]{6}{*}{ HS4 } & \multirow[t]{6}{*}{ Description } & HS6 & Description & HS8 & Description \\
\hline & & & & \multirow{3}{*}{410441} & \multirow{3}{*}{$\begin{array}{l}\text { Full grains leather, unsplit and grain splits leather, in the dry state crust, of hides and skins of } \\
\text { bovine incl. buffalo or equine animals, without hair on (excl. further prepared) }\end{array}$} & 41044110 & Whole leath. of bovines, dry state, grain splits $\mathrm{s}<=2.6 \mathrm{~m}^{2}$ \\
\hline & & & & & & 41044120 & Leat. of bovines, dry state, grain sp.tanned, for use as sole \\
\hline & & & & & & 41044130 & Other leathers/skins of bovines, dry state, grain slipts \\
\hline & & & & \multirow{2}{*}{410449} & \multirow{2}{*}{$\begin{array}{l}\text { Hides and skins of bovine incl. buffalo or equine animals, in the dry state crust, without hair } \\
\text { on, whether or not split (excl. further prepared and full grains, unsplit and grain splits) }\end{array}$} & 41044910 & Other leathers/skins, of bovines, dry state, $\mathrm{s}<=2.6 \mathrm{~m}^{2}$ \\
\hline & & & & & & 41044920 & Other leathers/skins of bovines, dry state \\
\hline & & \multirow{9}{*}{4107} & \multirow{9}{*}{$\begin{array}{c}\text { Leather further prepared } \\
\text { after tanning or crusting, } \\
\text { including } \\
\text { parchment-dressed leather, } \\
\text { of bovine (including buffalo) } \\
\text { or equine animals, without } \\
\text { hair on, whether or not split, } \\
\text { other than leather of } \\
\text { heading } 41144\end{array}$} & \multirow{2}{*}{410711} & \multirow{2}{*}{$\begin{array}{l}\text { Full grains leather incl. parchment-dressed leather, unsplit, of the whole hides and skins of } \\
\text { bovine incl. buffalo or equine animals, further prepared after tanning or crusting, without } \\
\text { hair on (excl. chamois leather, patent leather and patent laminated 1 }\end{array}$} & 41071110 & Whole leathers of bovines, full grains, prepared $\mathrm{s}<=2.6 \mathrm{~m}^{2}$ \\
\hline & & & & & & 41071120 & Oth. whole leathers/skins of bovines, full grain. prepar. \\
\hline & & & & \multirow{2}{*}{410712} & \multirow{2}{*}{$\begin{array}{l}\text { Grain splits leather incl. parchmente-dressed leather, of the whole hides and skins of bovine } \\
\text { incl. buffalo or equine animals, further prepared after tanning or crusting, without hair on } \\
\text { (excl. chamois leather, patent leather and patent laminated leather, }\end{array}$} & 41071210 & Whole leathers/skins of bovines, prepared $\mathrm{s}<=2.6 \mathrm{~m}^{2}$ \\
\hline & & & & & & 41071220 & Oth. whole leathers/skins of bovines, prepared, etc. \\
\hline & & & & \multirow{2}{*}{410719} & \multirow{2}{*}{$\begin{array}{l}\text { Leather incl. parchment-dressed leather of the whole hides and skins of bovine incl. buffalo } \\
\text { or equine animals, further prepared after tanning or crusting, without hair on (excl. unsplit } \\
\text { full grains leather, grain splits leather, chamois leather, patent } 1\end{array}$} & 41071910 & Whole leathers/skins of bovines, prepared $\mathrm{s}<=2.6 \mathrm{~m}^{2}$ \\
\hline & & & & & & 41071920 & Oth. whole leathers/skins of bovines, prepared \\
\hline & & & & 410791 & $\begin{array}{l}\text { Full grains leather incl. parchment-dressed leather, unsplit, of the portions, strips or sheets of } \\
\text { hides and skins of bovine incl. buffalo or equine animals, further prepared after tanning or } \\
\text { crusting, without hair on (excl. chamois leather, patent leath }\end{array}$ & 41079110 & Whole skins of bovines, prepar. full grains, unsplit \\
\hline & & & & 410792 & $\begin{array}{l}\text { Grain splits leather incl. parchment-dressed leather, of the portions, strips or sheets of hides } \\
\text { and skins of bovine incl. buffalo or equine animals, further prepared after tanning or crusting, } \\
\text { without hair on (excl. chamois leather, patent leather and p }\end{array}$ & 41079210 & Leathers/skins, bovines, prepared, grain splits \\
\hline & & & & 410799 & $\begin{array}{l}\text { Leather incl. parchment-dressed leather of the portions, strips or sheets of hides and skins of } \\
\text { bovine incl. buffalo or equine animals, further prepared after tanning or crusting, without } \\
\text { hair on }\end{array}$ & 41079910 & Other leathers/skins, bovines, prepared \\
\hline
\end{tabular}




\section{References}

1. Vermeulen, S.J.; Campbell, B.M.; Ingram, J.S.I. Climate Change and Food Systems. Annu. Rev. Environ. Resour. 2012, 37, 195-222. [CrossRef]

2. Wolosin, M.; Harris, N. Tropical Forests and Climate Change: The Latest Science; Working Paper; World Resources Institute: Washington, DC, USA, 2018; Available online: wri.org/ending-tropical-deforestation (accessed on 21 April 2020).

3. IPCC. Summary for Policymakers. Climate Change and Land: An IPCC Special Report on Climate Change, Desertification, Land Degradation, Sustainable Land Management, Food Security, and Greenhouse Gas Fluxes in Terrestrial Ecosystems. Shukla, P.R., Skea, J., Calvo Buendia, E., Masson-Delmotte, V., Pörtner, H.-O., Roberts, D.C., Zhai, P., Slade, R., Connors, S., et al., Eds.; In press. 2019. Available online: https: //www.ipcc.ch/site/assets/uploads/sites/4/2020/02/SPM_Updated-Jan20.pdf (accessed on 11 February 2020).

4. Cuypers, D.; Lust, A.; Geerken, T.; Gorissen, L.; Peters, G.; Karstensen, J.; Prieler, S.; Fisher, G.; Hizsnyik, E.; Van Velthuizen, H.; et al. The Impact of EU Consumption on Deforestation: Comprehensive Analysis of the Impact of EU Consumption on Deforestation: Final Report; Publications Office: Luxembourg, 2013.

5. Gibbs, H.K.; Ruesch, A.S.; Achard, F.; Clayton, M.K.; Holmgren, P.; Ramankutty, N.; Foley, J.A. Tropical forests were the primary sources of new agricultural land in the 1980s and 1990s. Proc. Natl. Acad. Sci. USA 2010, 107, 16732-16737. Available online: https://www.pnas.org/content/107/38/16732.short (accessed on 11 February 2020). [CrossRef] [PubMed]

6. Hosonuma, N.; Herold, M.; Sy, V.D.; Fries, R.S.D.; Brockhaus, M.; Verchot, L.; Angelsen, A.; Romijn, E. An Assessment of Deforestation and Forest Degradation Drivers in Developing Countries. Environ. Res. Lett. 2012, 7, 044009. [CrossRef]

7. Nepstad, D.; McGrath, D.; Stickler, C.; Alencar, A.; Azevedo, A.; Swette, B.; Bezerra, T.; DiGiano, M.; Shimada, J.; Motta, R.S.d.; et al. Slowing Amazon Deforestation through Public Policy and Interventions in Beef and Soy Supply Chains. Science 2014, 344, 1118-1123. [CrossRef] [PubMed]

8. Stabile, M.C.; Guimarães, A.L.; Silva, D.S.; Ribeiro, V.; Macedo, M.N.; Coe, M.T.; Pinto, E.; Moutinho, P.; Alencar, A. Solving Brazil's land use puzzle: Increasing production and slowing Amazon deforestation. Land Use Policy 2020, 9. [CrossRef]

9. Moutinho, P.; Guerra, R.; Azevedo-Ramos, C. Achieving Zero Deforestation in the Brazilian Amazon: What Is Missing? Elem. Sci. Anth. 2016, 4, 000125. [CrossRef]

10. INPE/Prodes/ TerraBrasil. Available online: http://terrabrasilis.dpi.inpe.br/en/home-page/ (accessed on 11 February 2020).

11. James, C.H. As the Amazon burns, cattle ranchers are blamed. But it's complicated. Natl. Geogr. 2019. Available online: https://www.nationalgeographic.com/culture/2019/08/amazon-burns-cattle-ranchersblamed-complicated-relationship/ (accessed on 11 February 2020).

12. OECD/FAO. Agricultural Outlook 2017-2026; OECD Publishing: Paris, France, 2017; Available online: https://doi.org/10.1787/agr_outlook-2017-en (accessed on 11 February 2020).

13. Lovejoy, T.E.; Nobre, C. Amazon Tipping Point. Science Advances 2018. Available online: https://advances. sciencemag.org/content/4/2/eaat2340?source=post_page-----1c8e343e7f0f-------------------- (accessed on 11 February 2020).

14. Kaimowitz, D.; Mertens, B.; Wunder, S.; Pacheco, P. Hamburger Connection Fuels Amazon Destruction; Center for International Forest Research: Bangor, Indonesia, 2004; pp. 1-10.

15. Rudel, T.K.; Defries, R.; Asner, G.P.; Laurance, W.F. Changing drivers of deforestation and new opportunities for conservation. Conserv. Biol. 2009, 23, 1396-1405. [CrossRef]

16. Pereira, M.D.A.; Jacinto, M.A.C.; Gomes, A.; Evaristo, L.G.S. Cadeia Produtiva Do Couro Bovino: Oportunidades E Desafios; Embrapa Gado de Corte: Campo Grande, MS, Brazil, 2005.

17. Barreto, P.; Marianno, B.; Valdiones, A.P.; Barreto, G. Os Frigoríficos vão Ajudar a Zerar o Desmatamento na Amazônia? Imazon and Instituto Centro Da Vida. 2017. Available online: http://www.imazon.org.br/ PDFimazon/Portugues/livros/Frigorificos $\% 20$ e $200 \% 20$ desmatamento\%20da\%20Amaz $\%$ C3\%B4nia.pdf (accessed on 11 February 2020).

18. Gibbs, H.; Munger, J.; L’Roe, J.; Barreto, P.; Pereira, R.; Christie, M.; Amaral, T.; Walker, N.F. Did ranchers and slaughterhouses respond to zero-deforestation agreements in the Brazilian Amazon? Conserv. Lett. 2016, 9 , 32-42. [CrossRef] 
19. MapBiomas. Map and Data, Land Use Change 1985-2017. Available online: http://mapbiomas.org/map\# coverage (accessed on 11 February 2020).

20. Mammadova, A.; Behagel, J.; Masiero, M. Making deforestation risk visible. Discourses on bovine leather supply chain in Brazil. Geoforum 2020. [CrossRef]

21. European Commission (EC). Trade. Policy. Countries and Regions. Brazil. 2019. Available online: https://ec.europa.eu/trade/policy/countries-and-regions/countries/brazil/ (accessed on 11 February 2020).

22. Pendrill, F.; Persson, U.M.; Godar, J.; Kastner, T. Deforestation Displaced: Trade in Forest-Risk Commodities and the Prospects for a Global Forest Transition. Environ. Res. Lett. 2019, 14, 055003. [CrossRef]

23. Chatham House. Available online: http://resourcetrade.earth/ (accessed on 11 February 2020).

24. Central Bank of Brazil. Foreign Direct Investment Report. 2018. Available online: https://www.bcb.gov.br/ Rex/CensoCE/ingl/FDIReport2016.pdf (accessed on 11 February 2020).

25. UN Comtrade Database. Available online: https://comtrade.un.org/ (accessed on 11 February 2020).

26. Italian Tanners Association (UNIC). Tales of Italian Leather. Sustain. Rep. 2017, 88. Available online: http://s.unic.it/5/report-en.html\#20-21 (accessed on 11 February 2020).

27. NYDF Assessment Partners. Protecting and Restoring Forests: A Story of Large Commitments yet Limited Progress. New York Declaration on Forests Five-Year Assessment Report. Clim. Focus 2019. Available online: forestdeclaration.org (accessed on 11 February 2020).

28. FERN. EU-Mercosur Deal Sacrifices Forests and Rights on the Altar of Trade. 2019. Available online: https://www.fern.org/news-resources/eu-mercosur-deal-sacrifices-forests-and-rights-onthe-altar-of-trade-1986/ (accessed on 11 February 2020).

29. Kehoe, L.; Reis, T.; Virah-Sawmy, M.; Balmford, A.; Kuemmerle, T. Make EU Trade with Brazil Sustainable. Science 2019, 364, 341-342. Available online: https://www.researchgate.net/publication/332665154_Make_ EU_trade_with_Brazil_sustainable (accessed on 11 February 2020). [PubMed]

30. Amazon Watch. Complicity in Destruction II. How Northern Consumers and Financiers Enable Bolsonaro's Assault on the Brazilian Amazon; Amazon Watch: Oakland, CA, USA, 2019. Available online: https: //amazonwatch.org/assets/files/2019-complicity-in-destruction-2.pdf (accessed on 11 February 2020).

31. Global Witness. Money to Burn. More than 300 Banks and Investors Back Six of the World's Most Harmful Agribusinesses to the Tune of \$44bn; Global Witness: Washington DC, USA, 2019. Available online: https://www.globalwitness.org/en/campaigns/forests/money-to-burn-how-iconic-banksand-investors-fund-the-destruction-of-the-worlds-largest-rainforests/ (accessed on 11 February 2020).

32. Faria, W.R.; Almeida, A.N. Relationship between Openness to Trade and Deforestation: Empirical Evidence from the Brazilian Amazon. Ecol. Econ. 2016, 121, 85-97. [CrossRef]

33. Harstad, B.; Mideksa, T.K. Conservation Contracts and Political Regimes. Rev. Econ. Stud. 2017, 84, 1708-1734. [CrossRef]

34. Robalino, J.; Herrera, L.D. Trade and Deforestation: A Literature Review; WTO Staff Working Paper, No. ERSD-2010-04; World Trade Organization (WTO): Geneva, Switzerland, 2010. [CrossRef]

35. Friis, C.; Nielsen, J.Ø. Telecoupling: Exploring Land-Use Change in a Globalised World; Springer: Berlin/Heidelberg, Germany, 2019.

36. Pendrill, F.; Persson, U.M.; Godar, J.; Kastner, T.; Moran, D.; Schmidt, S.; Wood, R. Agricultural and Forestry Trade Drives Large Share of Tropical Deforestation Emissions. Glob. Environ. Chang. 2019, 56, 1-10. [CrossRef]

37. Sandström, V.; Valin, H.; Krisztin, T.; Havlík, P.; Herrero, M.; Kastner, T. The Role of Trade in the Greenhouse Gas Footprints of EU Diets. Glob. Food Secur. 2018, 19, 48-55. [CrossRef]

38. Godar, J.; Persson, U.M.; Tizado, E.J.; Meyfroidt, P. Towards more accurate and policy relevant footprint analyses: Tracing fine-scale socio-environmental impacts of production to consumption. Ecol. Econ. 2015, 112, 25-35. [CrossRef]

39. Godar, J.; Suavet, C.; Gardner, T.A.; Dawkins, E.; Meyfroidt, P. Balancing Detail and Scale in Assessing Transparency to Improve the Governance of Agricultural Commodity Supply Chains. Environ. Res. Lett. 2016, 11, 035015. [CrossRef]

40. Kanemoto, K.; Moran, D.; Lenzen, M.; Geschke, A. International Trade Undermines National Emission Reduction Targets: New Evidence from Air Pollution. Glob. Environ. Chang. 2014, 24, 52-59. [CrossRef] 
41. European Commission. Stepping up EU Action to Protect and Restore the World's Forests; Communication from The Commission to the European Parliament, the Council, the European Economic and Social Committee and the Committee of the Regions: Brussels, Belgium, 2019. Available online: https://ec.europa.eu/info/sites/ info/files/communication-eu-action-protect-restore-forests_en.pdf (accessed on 11 February 2020).

42. Mammadova, A.; Sartorato, C.S.F.; Behagel, J.; Masiero, M.; Pettenella, D.M. Conceptualizing deforestation risk in commodity supply chains. The case of bovine leather. For. Policy Econom.. Under Review.

43. Centro das Indústrias de Curtumes do Brasil. Sobre o Couro. Available online: http://www.cicb.org.br/cicb/ sobre-couro (accessed on 11 February 2020).

44. Anonymous. EU-Mercosur, There Is An Agreement: Raw Hides from South America (finally) Opens Its Doors. La Conceria. 4 July 2019. Available online: https://www.laconceria.it/en/news/eu-mercosur-there-isan-agreement-raw-hides-from-south-america-finally-opens-its-doors/ (accessed on 11 February 2020).

45. Ermgassen, E.K.H.J.z.; Godar, J.; Lathuillière, M.J.; Löfgren, P.; Vasconcelos, A.; Gardner, T.; Meyfroidt, P. The Origin, Supply Chain, and Deforestation Footprint of Brazil's Beef Exports. Available online: https: //doi.org/10.31220/osf.io/efg6v (accessed on 20 February 2020).

46. Brazilian Leather Guide (BLG). Tannery List. 2017. Available online: http://www.guiabrasileirodocouro.com. br/ (accessed on 11 February 2020).

47. Cereceda, R.; Abellan-Matamoros, C. Brazil: State of Amazonas Declares State of Emergency over Rising Number of Forest Fires. Euronews. August 2019. Available online: https://www.euronews.com/2019/08/11/ brazil-state-of-amazonas-declares-state-of-emergency-over-rising-number-of-forest-fires (accessed on 11 February 2020).

48. Comexstat/MDIC. Available online: http://Comexstat.mdic.gov.br/pt/home (accessed on 11 February 2020).

49. Ministério da Economia, Indústria, Comércio Exterior e Serviços. Empresas Brasileiras Exportadoras e Importadoras. Available online: http://www.mdic.gov.br/index.php/comercio-exterior/estatisticas-decomercio-exterior/empresas-brasileiras-exportadoras-e-importadoras (accessed on 11 February 2020).

50. The Chambers of Commerce (Le Camere di Commercio). Registro Impresse. Available online: https: //www.registroimprese.it/en_US/company-registration-report-eng- (accessed on 11 February 2020).

51. Tattara, G.; Crestanello, P. Industrial Clusters and the Governance of the Global Value Chain: The Romania-Veneto Network in Footwear and Clothing: Regional Studies: Vol 45, No 2. Available online: https://www.tandfonline.com/doi/full/10.1080/00343401003596299?casa_token=kkODK1HNgi0AAAAA\% 3AQoet4oiMri2cVPgPOXVI8Pyh71UmGCmzpjJ7gD1nlqTiYrEPucfX2Dgr9gcySZnuQ_NZtkMimaQD (accessed on 11 February 2020).

52. Oliveira, L.J.C.; Costa, M.H.; Soares-Filho, B.S.; Coe, M.T. Large-scale expansion of agriculture in Amazonia may be a no-win scenario. Environ. Res. Lett. 2013, 8, 024021. [CrossRef]

53. Habermann, E.; Oliveira, E.A.D.d.; Contin, D.R.; Delvecchio, G.; Martinez, C.A.; Viciedo, D.O.; Moraes, M.A.d.; Prado, R.D.M.; Costa, K.A.d.P.; Braga, M.R. “Warming and water deficit impact leaf photosynthesis and decrease forage quality and digestibility of a C4 tropical grass.". Physiol. Plant. 2019, 165, 383-402.

54. Greenpeace. Slaughtering the Amazon. 2009. Available online: https://www.greenpeace.org/usa/research/ slaughtering-the-amazon/ (accessed on 11 February 2020).

55. Smeraldi, R.; May, P. A hora da conta: Pecuária, Amazônia e conjuntura. Amigos da Terra Amazônia Brasileira, 2009, São Paulo. Available online: http://commodityplatform.org/wp/wp-content/uploads/2009/05/a-horada-conta.pdf (accessed on 11 February 2020).

56. Swartz, J. How I Did It: Timberland's CEO on Standing Up to 65,000 Angry Activists. In Harvard Business Review on Greening Your Business Profitably; Harvard Business Press: Boston, MA, USA; pp. 197-2010.

57. Forest Trends. Supply Change Initiative. Search Company Commitments. Available online: http://supplychange.org/\#company-profiles (accessed on 11 February 2020).

58. Anonymous; (Cuiaba Mato Grosso Brazil). Personal Communication. 2018.

59. Cernansky, R. Is Footwear Funding the Burning of the Amazon? Vogue Business. August 2019. Available online: https://www.voguebusiness.com/companies/amazon-fires-footwear-leather-sustainability? (accessed on 11 February 2020).

60. Spring, J.; Slattery, G. Corporate Fallout for Brazil Heats up Despite Signs Amazon Fires May Be Slowing. Reuters. August 2019. Available online: https://www.reuters.com/article/us-brazil-environment/corporatefallout-for-brazil-heats-up-despite-signs-amazon-fires-may-be-slowing-idUSKCN1VJ1I2 (accessed on 11 February 2020). 
61. Andreoni, M.; Maheshwari, S. Is Brazilian Leather Out of Fashion? H\&M Stops Buying Over Amazon Fires. NY Times. September 2019. Available online: https://www.nytimes.com/2019/09/05/world/americas/h-mleather-brazil-amazon-fires.html (accessed on 11 February 2020).

62. Butler, R. Companies Sourcing Beef, Leather from China Exposed to Brazil Deforestation Risk, Researchers Say. Mongabay. August 2019. Available online: https://news.mongabay.com/2019/08/companies-sourcing-beefleather-from-china-exposed-to-brazil-deforestation-risk-researchers-say/ (accessed on 11 February 2020).

63. Leather Working Group. Traceability. Available online: https://www.leatherworkinggroup.com/how-wework/traceability (accessed on 11 February 2020).

64. Responsible Leather Round Table. About the Responsible Leather Round Table (RLRT). Available online: https://responsibleleather.org/about/ (accessed on 11 February 2020).

65. Ministério Público Federal do Brasil. Procuradoria da República no Pará. Auditorias Confirmam e Aprimoram Avanços No Controle da Origem da Carne no Pará. 2018. Available online: http://www.mpf.mp.br/pa/sala-de-imprensa/noticias-pa/auditorias-confirmam-e-aprimoramavancos-no-controle-da-origem-da-carne-no-para (accessed on 11 February 2020).

66. Gaworecki, M. Rotten Beef and Illegal Deforestation: Brazil's Largest Meatpacker Rocked by Scandals. Mongabay. 2017. Available online: https://news.mongabay.com/2017/04/rotten-beef-and-illegal-deforestationbrazils-largest-meatpacker-rocked-by-scandals/ (accessed on 11 February 2020).

67. Parra-Bernal, G.; Mello, G. Brazil Police Arrest JBS CEO Batista, Plea Deal in Limbo. Reuters. 2017. Available online: https://www.reuters.com/article/us-brazil-corruption-jbs-insidertrading/brazil-police-arrest-jbs-ceobatista-plea-deal-in-limbo-idUSKCN1BO17X (accessed on 11 February 2020).

68. Ministério Público Federal (MPF) do Brasil. Ações penais-Operação Arquimedes. Available online: http://www.mpf.mp.br/grandes-casos/operacao-arquimedes/atuacao-do-mpf/acoes-penais (accessed on 11 February 2020).

69. Branford, S.; Borges, T. In Brazil, Jair Bolsonaro's Government is Gutting Environmental Agencies from the Inside. 2019. Available online: https://psmag.com/environment/brazils-government-is-guttingenvironmental-protections-from-the-inside (accessed on 11 February 2020).

70. Watts, J. Deforestation of Brazilian Amazon Surges to Record High. The Guardian. 2019. Available online: https://www.theguardian.com/world/2019/jun/04/deforestation-of-brazilian-amazon-surges-torecord-high-bolsonaro (accessed on 11 February 2020).

71. Anonymous. Desmonte sob Bolsonaro Pode Levar Desmatamento da Amazônia a Ponto Irreversível, diz Físico que Estuda Floresta há 35 Anos. Globo Negocios. July 2019. Available online: https://epocanegocios.globo.com/Brasil/noticia/2019/07/desmonte-sob-bolsonaro-pode-levardesmatamento-da-amazonia-ponto-irreversivel-diz-fisico-que-estuda-floresta-ha-35-anos.html (accessed on 11 February 2020).

72. Institute of Quality Certification for the Leather Sector (ICEC). Certifications. Made in Italy of Leather Production. 2019. Available online: http://www.icec.it/en/certifications/product-economic-sustainability/ made-in-italy-of-leather-production (accessed on 11 February 2020).

73. Weatherley-Singh, J.; Gupta, A. "Embodied Deforestation" as a New EU Policy Debate to Tackle Tropical Forest Loss: Assessing Implications for REDD+ Performance. Forests 2018, 9, 751. [CrossRef]

74. European Commission. A Green Deal. Available online: https://ec.europa.eu/info/strategy/priorities-20192024/european-green-deal_en (accessed on 11 February 2020).

75. Byerlee, D.; Rueda, X. From Public to Private Standards for Tropical Commodities: A Century of Global Discourse on Land Governance on the Forest Frontier. Forests 2015, 6, 1301-1324. [CrossRef]

76. FERN. Support Solidifies for and EU Due-diligence Regulation. 2019. Available online: https://www.fern.org/ news-resources/support-solidifies-for-an-eu-due-diligence-regulation-2052/ (accessed on 11 February 2020).

77. Umunay, P.; Lujan, B.; Meyer, C.; Cobián, J. Trifecta of Success for Reducing Commodity-Driven Deforestation: Assessing the Intersection of REDD+ Programs, Jurisdictional Approaches, and Private Sector Commitments. Forests 2018, 9, 609. [CrossRef]

78. European Commission. Goal 15. Protect, Restore and Promote Sustainable Use of Terrestrial Ecosystems, Sustainably Manage Forests, Combat Desertification, and Halt and Reverse Land Degradation and Halt Biodiversity Loss. Available online: https://ec.europa.eu/sustainable-development/goal15_en (accessed on 11 February 2020). 
79. GreenLife. Three Years of the greenLIFE Project. 2014-2017. Layman's Report. 2017. Available online: https://www.slideshare.net/greenLIFEproject/green-life-laymans-report-en (accessed on 11 February 2020).

80. Italian Tanners Association (UNIC). L'industria Conciaria Italiana. Available online: http://www.unic.it/ conceria-italiana/industria-conciaria-italiana (accessed on 11 February 2020).

(C) 2020 by the authors. Licensee MDPI, Basel, Switzerland. This article is an open access article distributed under the terms and conditions of the Creative Commons Attribution (CC BY) license (http://creativecommons.org/licenses/by/4.0/). 